DOI: $\underline{10.20472 / E S .2018 .7 .2 .002 ~}$

\title{
CAUSAL NEXUS BETWEEN FDI, EXPORTS, UNEMPLOYMENT AND ECONOMIC GROWTH FOR THE OLD EUROPEAN UNION MEMBERS. EVIDENCE FROM PANEL DATA
}

\author{
NIKOLAOS DRITSAKIS, PAVLOS STAMATIOU
}

\begin{abstract}
:
This study examines the causality relationships between foreign direct investments (FDI), exports, unemployment and economic growth in the fifteen old EU members using panel data covering the period 1970-2015. The Hausman test is applied for choosing between Fixed Effect and Random Effect approach in order to estimate the panel VAR equations for Granger causality tests. The results revealed three bidirectional causalities between economic growth and exports, exports and FDI, and exports and unemployment and three unidirectional causalities running from FDI to economic growth, FDI to unemployment and from economic growth to unemployment. Policy implications are then explored in the conclusions.
\end{abstract}

\section{Keywords:}

Economic growth; Foreign direct investments; Exports; Unemployment; Panel analysis; Causality

JEL Classification: C22, E31, E50

\section{Authors:}

NIKOLAOS DRITSAKIS, University of Macedonia, Economics and Social Sciences, Greece, Email: drits@uom.gr PAVLOS STAMATIOU, University of Macedonia, Economics and Social Sciences, Greece, Email: stamatiou@uom.edu.gr

\section{Citation:}

NIKOLAOS DRITSAKIS, PAVLOS STAMATIOU (2018). Causal Nexus between FDI, Exports, Unemployment and Economic Growth for the Old European Union Members. Evidence from Panel Data. International Journal of Economic Sciences, Vol. VII(2), pp. 35-56., 10.20472/ES.2018.7.2.002 


\section{Introduction}

The European Union (EU) was created in 1993 with the Maastricht Treaty. In 1993 the Union had twelve members. Since then, several enlargements have increased the number of member states. The enlargement of May $1^{\text {st }}, 2004$ was the biggest enlargement in its history and changed the framework for economic activities in Europe. Ten new countries acceded to the EU, eight of which belong to Eastern Europe: Estonia, Cyprus, Latvia, Lithuania, Malta, Hungary, Poland, Slovakia, Czech Republic and Slovakia. Afterwards, in 2007 Bulgaria and Romania joined the Union and in 2013 Croatia also joined.

With the accession of these countries, in 2013 the real Gross Domestic Product (GDP) in the EU reached approximately 13000 billion euro (AMECO 2014). The total GDP of the thirteen new members does not exceed $7 \%$ of European Union's GDP, while at the same time reduced significantly the average GDP per capita of the old members, EU15 (countries that acceded to the EU before May 15t, 2004: Belgium, Denmark, Germany, Ireland, Greece, Spain, France, Italy, Luxemburg, Netherlands, Austria, Portugal, Finland, Sweden, United Kingdom). However, this loss in GDP was quickly compensated by the rules of market economies which led to greater competition. Increased competition is also positive for European consumers as far as the prices, the variety of goods and services, the quality of goods and services and generally the consumer's protection. A safer legal environment can create a sustainable macroeconomic framework and it constitutes the trigger for investment stability.

Nevertheless, it would be wrong to say that the enlargement of the EU has not influenced the old member states. The thirteen recent accessions have changed the economic framework in Europe since they have led to economies of scale, have increased the trade in goods and services, have increased the competition as well as the investment flows. Also, given the conditions of free trade and labor mobility the investment framework has changed a lot.

The majority of the old EU members, in contrast with the new member states, are high income countries with significantly higher wages. So, we could say that the new members could be attractive in foreign direct investments (FDI). FDI are stimulated in many countries only with the prospect of the accession in EU. Many companies located in the EU15 decide to create new production units in the new neighboring developing countries due to the low-cost labor supply. However, it is worth to say that the strength of the investment flows is also depended on the country specific characteristics and the proviso that economic conditions in the host countries are favorable.

On the other hand, many economists believe that developed economies attract more FDI because they have higher growth rates, are more productive and more profitable economies and they can absorb more easily new technologies. The thirteen new EU countries have not won, so far, significant FDI amounts from the older members. So, the fact that the new member states are lower cost production countries is a key factor for FDI attraction, but it would be wrong to say that it is the only factor. The level of taxation, 
the market size of the host country, the openness of the domestic economy, the labor cost, the economic and political stability and the geographic position of the country are some of them.

The impact of foreign direct investments on economic performance is a popular subject among policymakers. Global economic crisis had as a result a large number of studies which investigate the relationship between FDI and economic growth. Most of the studies showed that FDI has a positive effect in host countries economies. FDI inflows can promote exports, boost economic development, promote technical innovation and help in reducing unemployment. In recent years many European countries have been interested in attracting FDI in order to enhance their economic performance and facilitate job creation.

Nevertheless, we cannot say that there is universal agreement regarding the relationship between FDI and economic development. Studies showed that the relationship between these variables is not clear, especially in the developing countries. However, the positive impact of FDI appears to be greater on the economy of developed countries, since their markets can be adjusted more easily in the new competitive conditions. The purpose of this study is to examine the causal links between FDI, exports, unemployment and economic growth in the fifteen old European Union countries over the period 1970-2015. Many these countries are under recession the last few years. Increased unemployment rates and negative or decreased growth rates are some of the mains problems that they have to face. However, economic crisis did not have the same impact in these countries. This depended on the infrastructure and the level of the domestic economy of each country.

To our knowledge there are very few studies in the literature that investigate the causal relationship between these four variables together. Also, there are even fewer studies that carried out their analysis in the panel framework.

The structure of the paper is as follows: Section 2 briefly reviews the literature. Section 3 presents data and variables. This is followed by section 4 which presents methodology. Empirical results are discussed in section 5. Concluding remarks are given in the final section.

\section{Theoretical Background and Literature Review}

There is a widespread belief among economists that FDI inflows can play a vital role in a host country. FDI can influence exports, wages, competitive conditions, productivity and therefore the economic development. Denisia (2010) believed that FDI affects economic growth both directly and indirectly through exports. FDI increases exports and then exports boost economic development. Borensztein, De Gregorio and Lee (1998) argued that FDI enhances technology transfer and then promotes economic growth in the host country economy. Also, De Mello (1997) supported that FDI enhances the production process, increases capital adequacy and transfers knowledge and 
technology both in terms of labor training and skill acquisition. Bailey and Driffield (2007) examined the effects of trade, inward FDI and technological development both for skilled and unskilled workers for the case of UK. The results showed that both trade and FDI have a positive effect on skilled workers. On the contrary, FDI and trade affect negatively the demand for unskilled workers.

On the other hand, there are studies which supports that FDI is not beneficial for all countries. Huang and Zhang (2007) argued that the impact of FDI on employment is not obvious. Also, they supported that FDI has no influence on wages. Brady and Wallace (2000) examined the impact of FDI on employment and labor income for the case of U.S., under the spatialization theory. They found that FDI has a negative impact on employment level and labor income, for the period that the study was conducted.

In the following paragraphs we mention studies, from recent empirical literature, on the relationship between foreign direct investments, exports, unemployment and economic growth in one country as well as in a group of countries. The results obtained from these studies are diversified and depend on the country (developed or developing), the period and the econometric method that is applied.

Chag (2005) examined the dynamic interactions between FDI, economic growth, exports and unemployment for Taiwan over the period 1981-2003. The findings suggest that both economic growth and exports have a positive impact on FDI inflows. However, exports have a negative impact on FDI outflows. Moreover, evidence suggests that FDI inflows have a positive impact on exports and economic growth. Also, the results show that there is a negative relationship between economic growth and unemployment and a positive relationship between economic development and exports.

Aktar and Ozturk (2009) investigated the relationship between FDI, exports, unemployment and GDP for Turkey over the period 2000-2007. They found that exports attract more FDI to the country but FDI does not help in reducing unemployment. Also the results show that economic growth does not reduce the unemployment rate either. The results might suggest that the policy priority for Turkey seems to be the attraction of more FDI in order to boost economic performance through knowledge and technology transfer.

Yilmaz (2014) examined the relationship between FDI inflows, exports, unemployment and economic growth for Turkey using data for the period 2000-2013. The results of this study showed that there is a negative relationship between unemployment and economic growth, exports. Moreover, there is a positive relationship between unemployment and FDI. Therefore, FDI inflows do not generate employment in Turkey, for the examined period. Turkey should implement polices to attract green field investments to enhance employment.

Stamatiou and Dritsakis (2014) investigated the impact of FDI on the unemployment rate and economic growth in Greece using data for the period 1970-2012. Their results confirmed a strong unidirectional causality between GDP and FDI with direction from GDP to FDI. Greek government should focus on the attraction of foreign capitals. The 
attraction of these funds combined with debt reduction will boost economic development and will help in reducing unemployment.

There are also studies that examine the relationship between these variables in a group of countries. Ciftcioglu, Fethi and Begovic (2007) examined the impact of net FDI inflows on economic growth, unemployment and openness in nine Central and East European countries for the period 1995-2003. The major finding of this study is that increases in net FDI inflows have negative impact on unemployment. So, these countries should implement policies that can increase the positive effects of FDI inflows on productivity growth, technological progress and therefore economic development.

Dritsakis and Stamatiou (2014) investigated the relationship between FDI, exports, and GDP in five Eurozone countries using panel data for the period 1970-2011. They found that there is bidirectional causality between exports and economic development, while there is no causality between economic growth and FDI nor between FDI and exports. The results of this study show that an increase in domestic products of these countries will cause a dynamic impulse in exports and economic growth.

A similar study (Mehrara, Haghnejad and Dehnavi 2014) investigated the casual links among GDP, exports and FDI for 57 developing countries over the period 1980-2008. The results of the study showed that there is bidirectional causality relation between FDI and GDP and a unidirectional relation running from exports to GDP. On the other hand, GDP and FDI do not cause exports. The obtained results suggest that these countries should implement policies to attract more FDI and increase their exports in order to achieve higher growth rates.

Table 1 Summary of studies showing causal link between FDI, exports, unemployment and economic growth

\begin{tabular}{|c|c|c|c|c|}
\hline Authors & Period & Country & Variables & Method \\
\hline \multicolumn{2}{|c|}{ Studies using time series data } & & $\begin{array}{c}\text { VAR } \\
\text { Chang } \\
(2005)\end{array}$ \\
\hline & $1981-2003$ & Taiwan & $\begin{array}{c}\text { FDI, exports, } \\
\text { vannique of } \\
\text { variance } \\
\text { decomposition } \\
\text { and impulse } \\
\text { response } \\
\text { function } \\
\text { analysis }\end{array}$ \\
$\begin{array}{c}\text { Aktar and } \\
\text { Ozturk } \\
(2009)\end{array}$ & $2000-2007$ & Turkey & FDI, exports, & $\begin{array}{c}\text { VAR } \\
\text { technique of } \\
\text { variance } \\
\text { decomposition } \\
\text { and impulse } \\
\text { response }\end{array}$ \\
\hline
\end{tabular}




\begin{tabular}{|c|c|c|c|c|}
\hline & & & & $\begin{array}{l}\text { function } \\
\text { analysis }\end{array}$ \\
\hline $\begin{array}{l}\text { Yilmaz } \\
(2014)\end{array}$ & $2000-2013$ & Turkey & $\begin{array}{c}\text { FDI, exports, } \\
\text { unemployment, GDP }\end{array}$ & $\begin{array}{c}\text { ARDL } \\
\text { approach and } \\
\text { ECM-ARDL } \\
\text { model }\end{array}$ \\
\hline $\begin{array}{c}\text { Stamatiou } \\
\text { and } \\
\text { Dritsakis } \\
(2014)\end{array}$ & $1970-2012$ & Greece & $\begin{array}{l}\text { FDI, unemployment, } \\
\text { GDP }\end{array}$ & $\begin{array}{c}\text { ARDL } \\
\text { approach and } \\
\text { ECM-ARDL } \\
\text { model }\end{array}$ \\
\hline \multicolumn{5}{|c|}{ Studies using panel data } \\
\hline $\begin{array}{l}\text { Ciftcioglu, } \\
\text { Fethi and } \\
\text { Begovic } \\
(2007)\end{array}$ & $1995-2003$ & $\begin{array}{c}\text { Nine } \\
\text { Central and } \\
\text { East EU } \\
\text { countries }\end{array}$ & $\begin{array}{l}\text { FDI, openness, } \\
\text { GDP, unemployment }\end{array}$ & $\begin{array}{l}\text { Panel data } \\
\text { regression } \\
\text { analysis }\end{array}$ \\
\hline $\begin{array}{l}\text { Dritsakis } \\
\text { and } \\
\text { Stamatiou } \\
(2014)\end{array}$ & $1970-2011$ & $\begin{array}{l}\quad \text { Five } \\
\text { Eurozone } \\
\text { countries }\end{array}$ & FDI, exports, GDP & $\begin{array}{l}\text { Panel VAR } \\
\text { and Granger } \\
\text { causality test }\end{array}$ \\
\hline $\begin{array}{l}\text { Mehrara, } \\
\text { Haghnejad } \\
\text { and } \\
\text { Dehnavi } \\
\text { (2014) }\end{array}$ & $1980-2008$ & $\begin{array}{c}57 \\
\text { developing } \\
\text { countries }\end{array}$ & FDI, exports, GDP & $\begin{array}{c}\text { Panel } \\
\text { generalized } \\
\text { method } \\
\text { moment } \\
\text { (GMM) }\end{array}$ \\
\hline
\end{tabular}

\section{Data structure and variables}

The variables that are used in this study are gross domestic product (GDP), exports of goods and services (EXP) and foreign direct investments inflows ${ }^{1}$ (FDI inflows) measured in constant 2005 US dollars, expressed in million and unemployment (UN) expressed as a percentage of civilian labor force. The data are annual covering the period 1970-2015. Data are gathered from economic databases World Development Indicator (WDI 2014), Annual Macro-Economic (AMECO 2014) and United Nations Conference on Trade and Development (UNCTAD 2014).

The descriptive statistics of the panel data used in this study are shown in Table 2.

1. Data from 1970 to 2001 inclusive refer to Belgium-Luxembourg. From 2002 onwards data cover Belgium only (UNCTAD 2014). 
Table 2 Descriptive statistics

\begin{tabular}{|l|c|c|c|c|}
\hline & GDP & FDI & EXP & UN \\
\hline Mean & 644368.0 & 11174.07 & 177358.3 & 6.893798 \\
\hline Median & 261442.7 & 1767.880 & 96344.51 & 6.400000 \\
\hline Maximum & 3073861.2 & 200039.2 & 1603561. & 25.00000 \\
\hline Minimum & 9232.452 & -31689.30 & 5243.769 & 0.000000 \\
\hline Std. Dev. & 730142.6 & 24647.14 & 221070.1 & 4.116407 \\
\hline Skewness & 1.378470 & 4.066634 & 2.866762 & 0.962108 \\
\hline Kurtosis & 3.845428 & 24.83051 & 14.39848 & 4.332244 \\
\hline Jarque-Bera & 223.4783 & 14585.63 & 4375.211 & 147.2073 \\
\hline Probability & 0.000000 & 0.000000 & 0.000000 & 0.000000 \\
\hline Observations & 690 & 690 & 690 & 690 \\
\hline
\end{tabular}

\section{Methodololgy}

This paper employs Granger causality test in a Vector Autoregressive (VAR) framework to test the causal nexus between economic growth, FDI inflows, exports and unemployment. We begin applying Im, Pesaran and Shin (2003) panel unit root test in order to examine the stationarity of the four variables.

\subsection{Panel Unit Root Test}

\subsubsection{IPS Unit Root Test}

We begin our analysis with the examination of the stationarity properties of all the variables included in the model. The literature divides panel unit root tests into first and second-generation tests. The first generation assume that panel data do not exhibit a cross-sectional dependence in the errors, while the second generation take under consideration the cross-sectional dependency. According to Breusch and Pagan (1980) and Pesaran (2004) the existence of cross sectional dependence between the series can affect the whole panel significantly. In this study, we begin applying the IPS first 
generation unit root test proposed by Im, Pesaran and Shin (2003). This approach allows the heterogeneity between cross section units.

Im, Pesaran and Shin (2003) proposed a test for the presence of unit root in panel data. Many of these economies that we study have similar problems the last few years due to economic crisis, such as negative or decreased growth rates, high unemployment, large public debt and budget deficits. However, they are different countries with different population, different structure of economy and different working conditions.

IPS begins by specifying a separate ADF (Augmented Dickey Fuller) regression for each cross section:

$$
\Delta y_{i t}=\alpha_{i}+\rho_{i} y_{i t-1}+\sum_{L=1}^{p_{i}} \beta_{i L} \Delta y_{i t-L}+\varepsilon_{i t}
$$

where $\mathrm{i}$ denotes the cross section unit $i=1,2 \ldots, N$, t time period $t=1,2 . ., T, y_{i t}$ is the series for panel member (country) $i$ over period $t, p_{i}$ is the number of lags in the ADF regression, and $\varepsilon_{i, t}$ are the error terms assumed to be independently and normally distributed $\varepsilon_{i, t} \rightarrow N\left(0, \sigma_{i, t}^{2}\right)$. The null hypothesis is that all individuals follow a unit root process against the alternative which allows some (but not all) of the individuals to have unit roots:

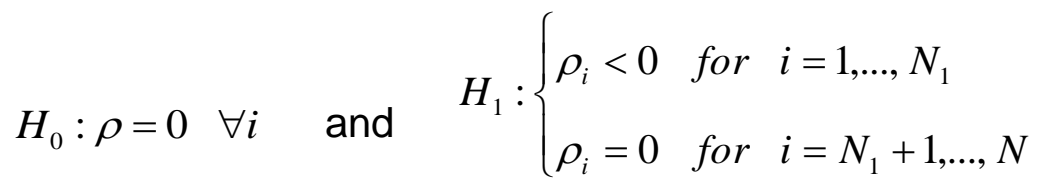

The test is based on the average of the t-statistics from the individual ADF regressions, for each cross section:

$$
\bar{t}_{N, T}=\frac{1}{N} \sum_{i=1}^{N} t_{i, T} \quad \text { and } \quad \sqrt{N} \frac{\left(\bar{t}_{N, T}-\mu\right)}{\sigma} \rightarrow N(0,1)
$$

Monte Carlo simulations show that IPS test has better performance when the sample is small. If either $N$ is small or if $N$ is large relative to $T$ then the test indicates size distortions. Additionally, the tests have little power if deterministic terms are included in the analysis (Kunst 2009). 


\subsubsection{Cross Sectional Dependence Test}

The assumption that panel data do not exhibit a cross-sectional dependence in the errors is not valid in the empirical investigation. Panel data models are more likely to exhibit a cross-sectional dependence in the errors, which may arise due to unobserved common factor, the presence of common shocks, regional and macroeconomic linkages and general residual interdependence (De Hoyos and Sarafidis 2006)

The most well-known cross section dependence diagnostic is the Breusch-Pagan (1980) test. Breusch and Pagan (1980) proposed a Lagrange Multiplier (LM) statistic given by:

$$
L M=T\left(\sum_{i=1}^{N-1} \sum_{j=i+1}^{N} \rho_{i j}^{2}\right)
$$

where $\rho_{i j}$ are the correlation coefficients obtained from the residuals of the model as described above. For both tests, the null hypothesis is that there isn't cross-sectional dependence in the panel. Under the null hypothesis, the statistic has a chi-square asymptotic distribution with $\mathrm{N}(\mathrm{N}-1) / 2$ degrees of freedom.

\subsubsection{CIPS Unit Root Test}

Since cross-sectional dependence among countries has been determined, we continue applying the CIPS second generation unit root test proposed by Pesaran (2007). The procedure of CIPS test begins with the OLS estimation for the $i^{\text {th }}$ cross section in the panel considering the following Cross-Sectional Augmented Dickey Fuller (CADF) regression:

$$
\Delta y_{i t}=\alpha_{i}+\rho_{i} y_{i, t-1}+\delta_{i} \bar{y}_{i, t-1}+\sum_{j=0}^{k} \delta_{i j} \Delta \bar{y}_{i, t-j}+\sum_{j=0}^{k} \Delta y_{i, t-j}+\varepsilon_{i t}
$$

where: $\bar{y}_{i, t-1}=\left(\frac{1}{N}\right) \sum_{i=1}^{N} y_{i, t-1}, \Delta \bar{y}_{t}=\left(\frac{1}{N}\right) \sum_{i=1}^{N} y_{i, t}$ and $t_{i}(N, T)$ is the t-statistic of $\rho_{i}$ that is used for the computation of the individual ADF statistic. CIPS statistic is based on individual CADF average statistics. Equation of CIPS is as follows:

$C I P S=\left(\frac{\sum_{i=1}^{N} C A D F_{i}}{N}\right)$ 
Pesaran (2007) has tabulated the critical values for CIPS for various deterministic terms. If calculated CIPS value is smaller than the table the critical value, the null hypothesis of non stationarity is rejected.

\subsection{Panel Data Regression Models}

When we estimate panel data regression models, we consider various assumptions about the intercept, the slope coefficients, and the error term. This procedure requires selecting between fixed effects (FE) model, random effects (RE) model and pooled regression model (Greene 2003).

\subsubsection{Fixed Effects Model}

The fixed effects (FE) approach has the feature that the intercept differs between cross section units but does not vary over time. The FE model has the following form:

$$
y_{i t}=\alpha_{i}+\beta x_{i t}+u_{i t}
$$

where $\mathrm{i}$ denotes the cross sectional unit $i=1,2 \ldots, N$, t time period $t=1,2 . ., T, y_{i t}$ is one of the endogenous examined variables. The constant $\alpha_{i}$ integrates all unobserved and time invariant factors that influence $y_{i t} \cdot x_{i t}$ is a vector that contains the lags of the endogenous variables. $\beta$ is a column vector of slope coefficients for the group of countries. The error term $u_{i t}$ follows asymptotically the normal distribution $u_{i t} \rightarrow N\left(0, \sigma_{u}^{2}\right)$ The main purpose of the model is the estimation of parameter $\beta$ in a way that ensures the consistency of results. We begin with the expected value of equation (5) for each i, which give us the average:

$$
\overline{y_{i}}=\alpha_{i}+\beta \overline{x_{i}}+\overline{u_{i}}
$$

where: $\overline{y_{i}}=\frac{1}{T} \sum_{t=1}^{T} y_{i t}, \overline{x_{i}}=\frac{1}{T} \sum_{t=1}^{T} x_{i t}, \overline{u_{i}}=\frac{1}{T} \sum_{t=1}^{T} u_{i t}$

The average of $\alpha_{i}$ for a given i does not vary over time. Subtracting (6) from (5) derives the following equation:

$y_{i t}-\overline{y_{i}}=\beta\left(x_{i t}-\overline{x_{i}}\right)+\left(u_{i t}-\overline{u_{i}}\right), \quad$ with $t=1,2, \ldots, T$ 
The estimator of $\beta$ is called fixed effects estimator or within estimator and it is obtained by applying the method of Least Squares (OLS) in equation (7):

$\beta_{F E}=\left[\sum_{i=1}^{N} \sum_{i=1}^{T}\left(x_{i t}-\overline{x_{i}}\right)\left(x_{i t}-\overline{x_{i}}\right)^{\prime}\right]^{-1} \sum_{i=1}^{N} \sum_{t=1}^{T}\left(x_{i t}-\overline{x_{i}}\right)\left(y_{i t}-\overline{y_{i}}\right)$

$\beta_{F E}$ is unbiased when $\mathrm{N}$ is finite and $x_{i t}$ is not correlated with error term $u_{i t}$ and consistent when $x_{i t}$ does not depend on the error terms of the current period $u_{i t}$, neither of the previous nor of the future periods (assumption of strict exogeneity). In the FE model, there is no restriction as regards the relationship between $x_{i t}$ and $\alpha_{i}$.

An alternative but equivalent approach leading to the same estimator is the Least Squares Dummy Variable (LSDM) method. We create a dummy variable for each of the $\mathrm{N}$ cross sections. Then we estimate an OLS regression of the dependent variable on $\mathrm{N}$ dummy variables and on explanatory variables as shown below:

$y_{i t}=\sum_{j=1}^{N} \alpha_{j} d_{j, i t}+x_{i t} \beta+u_{i t}, \quad$ where: $d_{j, i t}=\left\{\begin{array}{lll}1 & \text { if } & j=i \\ 0 & \text { if } & j \neq i\end{array}\right\}$

The estimator of $\beta$ coincides with the FE estimator and therefore is consistent under the same assumptions.

Consistent estimation of $\beta$ and $\alpha$ is not guaranteed for short panels. The estimation of $\beta$ can be consistent even if $\alpha$ is estimated inconsistently, unless additionally $T \rightarrow \infty$ (Cameron and Trivedi 2005).

\subsubsection{Random Effects Model}

The random effects (RE) approach has as main feature the random behavior of individual effects. Assume that intercept is a random variable $\alpha_{i}=\alpha+\varepsilon_{i}$. Therefore, we have a model with two error terms (two error component model). We modify the equation (5) as shown below in order to obtain the random effects equation:

$$
y_{i t}=\alpha+x_{i t} \beta+v_{i t}, \quad \text { where: } v_{i t}=\varepsilon_{i}+u_{i t}
$$


Because of the autocorrelation resulting from the combined error term $v_{i t}=\varepsilon_{i}+u_{i t}\left(v_{i t}\right.$ and $v_{i k}$ for $\mathrm{t} \neq \mathrm{k}$ are correlated), the Generalized Least Squares (GLS) method is recommended for the estimation of the $\mathrm{RE}$ model. The random effects estimator is the feasible generalized least squares (GLS) estimator:

$\beta_{G L S}=\Delta \beta_{B}+(1-\Delta) \beta_{F E}$

where: $\beta_{G L S}=\beta_{R E}, \Delta$ is a weighting matrix and is proportional to the inverse of the covariance matrix of $\beta_{B}$ (Hsiao 2003) and $\beta_{B}$ the between estimator:

$\beta_{B}=\left[\sum_{i=1}^{N}\left(\overline{x_{i}}-\bar{x}\right)\left(\overline{x_{i}}-\bar{x}\right)^{\prime}\right]^{-1} \sum_{i=1}^{N}\left(\overline{x_{i}}-\bar{x}\right)\left(\overline{y_{i}}-\bar{y}\right)$

where: $\bar{x}=\frac{1}{N T} \sum_{i=1}^{N} \sum_{t=1}^{T} x_{i t}$ and $\bar{y}=\frac{1}{N T} \sum_{i=1}^{N} \sum_{t=1}^{T} y_{i t}$

When $\alpha_{i}$ is correlated with $\bar{x}_{i}$, the between estimator is biased, so it is not appropriate for the fixed effects estimator.

\subsubsection{Pooled OLS}

The most restrictive model is the pooled model where the intercept $\alpha$ and the slope coefficients do not vary either as to $i$ or as to $t$. The individual effects are common for all cross sections units (homogeneity). The pooled regression model is shown in the following equation:

$y_{i t}=\alpha+x_{i t} \beta+u_{i t}$

with $i=1, \ldots, N$ and $t=1, \ldots, T$

If this model is correctly specified, then under the assumption of strict exogeneity it can be consistently estimated using pooled OLS. The pooled OLS estimator is inconsistent in the case that the FE model is valid. Adding and subtracting the constant term $\alpha$ in equation (5) we have:

$y_{i t}=\alpha+\beta x_{i t}+\left(\alpha_{i}-\alpha+u_{i t}\right)$ 
If individual affect $\alpha_{i}$ is correlated with the regressors $x_{i t}$ then the combined error $\left(\alpha_{i}-\alpha+u_{i t}\right)$ is correlated with the regressors (Cameron and Trivedi 2005).

\subsection{Hausman Test}

The choice between random effects models and fixed effects model can be done applying Hausman (1978) test. The choice depends on the correlation assumption between unit effects and $x$-variables. The fixed effects (FE) estimator is consistent when unit effects are correlated with $x$-variables contrary to the random effects (RE) estimator which is inconsistent. The null hypothesis for the Hausman's test statistic is that there is no difference between FE and RE estimator, against the alternative that there is a statistically significant difference between FE and RE estimator (Ho: difference in coefficients not systematic). Rejection of the null hypothesis means that the random effects assumption of strict exogeneity is not true. The test of the null hypothesis is based on the statistical criterion:

$$
H=\left(\hat{\beta}_{F E}-\hat{\beta}_{R E}\right)^{\prime}\left[\operatorname{Var}\left(\hat{\beta}_{F E}\right)-\operatorname{Var}\left(\hat{\beta}_{R E}\right)\right]^{-1}\left(\hat{\beta}_{F E}-\hat{\beta}_{R E}\right)
$$

which follows asymptotically the $\mathrm{X}^{2}$ distribution with the number of degrees of freedom equal to the rank of matrix $\operatorname{Var}\left(\hat{\beta}_{F E}\right)-\operatorname{Var}\left(\hat{\beta}_{R E}\right)$ (where: $\operatorname{Var}$ symbolizes the variance).

This test was generalized by Arellano (1993) to make it robust to heteroskedasticity and autocorrelation of arbitrary forms. The Hausman's test statistic is inappropriate if heteroskedasticity or serial correlation exists (Baltagi 1988).

\subsection{Panel Data VAR and Granger Causality Tests}

In this study we use panel data VAR with lag order 2 in order to analyze the causal relationships between the examined variables. The optimal lag length selected by the minimum value of Schwarz criterion. The equations that are used to test Granger causality are the following:

$$
\begin{gathered}
\Delta G D P_{i, t}=\beta_{1 i}+\sum_{k=1}^{p} \beta_{11 i k} \Delta G D P_{i, t-k}+\sum_{k=1}^{p} \beta_{12 i k} \Delta F D I_{i, t-k}+\sum_{k=1}^{p} \beta_{13 i k} \Delta E X P_{i, t-k}+\sum_{k=1}^{p} \beta_{14 i k} \Delta U N_{i, t-k}+u_{1 i, t} \\
\Delta F D I_{i, t}=\beta_{2 i}+\sum_{k=1}^{p} \beta_{21 i k} \Delta G D P_{i, t-k}+\sum_{k=1}^{p} \beta_{22 i k} \Delta F D I_{i, t-k}+\sum_{k=1}^{p} \beta_{23 i k} \Delta E X P_{i, t-k}+\sum_{k=1}^{p} \beta_{24 i k} \Delta U N_{i, t-k}+u_{2 i, t}
\end{gathered}
$$




$$
\begin{aligned}
& \Delta E X P_{i, t}=\beta_{3 i}+\sum_{k=1}^{p} \beta_{31 i k} \Delta G D P_{i, t-k}+\sum_{k=1}^{p} \beta_{32 i k} \Delta F D I_{i, t-k}+\sum_{k=1}^{p} \beta_{33 i k} \Delta E X P_{i, t-k}+\sum_{k=1}^{p} \beta_{34 i k} \Delta U N_{i, t-k}+u_{3 i, t} \\
& \Delta U N_{i, t}=\beta_{4 i}+\sum_{k=1}^{p} \beta_{41 i k} \Delta G D P_{i, t-k}+\sum_{k=1}^{p} \beta_{42 i k} \Delta F D I_{i, t-k}+\sum_{k=1}^{p} \beta_{43 i k} \Delta E X P_{i, t-k}+\sum_{k=1}^{p} \beta_{44 i k} \Delta U N_{i, t-k}+u_{4 i, t}
\end{aligned}
$$

where $\Delta$ is the first difference operator, $p$ is the optimal lag length and $u_{j, i, t} \quad(j=1,2,3$, 4 ) is the disturbance term assumed to be uncorrelated with zero means.

\section{Empirical Results}

In the empirical analysis we use annual data concerning GDP, FDI inflows, EXP and UN for the fifteen countries. We begin by testing the stationarity of these variables.

\subsection{Unit Root Results}

\subsubsection{IPS Unit Root Results}

Applying the unit root test of Im, Pesaran and Shin (2003) we present the results in table 3.

\section{Table 3 Panel data unit root test}

\begin{tabular}{|c|c|c|}
\hline \multirow{2}{*}{ Variables } & \multicolumn{2}{|c|}{ Im, Pesaran and Shin (IPS) } \\
\hline GDP & $3.895(1.000)$ & Individual intercept and trend \\
\hline DGDP & $-12.433(0.000)^{* * *}$ & $0.226(0.589)$ \\
\hline FDI & $-1.825(0.034)^{* *}$ & $-10.703(0.000)^{* * *}$ \\
\hline DFDI & $-13.609(0.000)^{* * *}$ & $-5.217(0.000)^{* * *}$ \\
\hline EXP & $11.110(1.000)$ & $-11.335(0.000)^{* * *}$ \\
\hline DEXP & $-16.333(0.000)^{* * *}$ & $2.273(0.988)$ \\
\hline UN & $-1.093(0.137)$ & $-14.987(0.000)^{* * *}$ \\
\hline DUN & $-10.064(0.000)^{* * *}$ & $-0.596(0.275)$ \\
\hline
\end{tabular}


Notes: Panel data include all countries. The numbers in parentheses denote p-values. ${ }^{* * *},{ }^{* *}$ denotes rejection of null hypothesis at the $1 \%$ and $5 \%$ level of significance, respectively. The null hypothesis of the test is that the panel series has a unit root. Lag length selection automatic based on Schwarz criterion.

As can be seen from table 3 , the test results showed that FDI is stationary in levels, while the other three variables contain a unit root. Also, the test results indicated that all variables are stationary in their first differences.

\subsubsection{Cross-Sectional Dependence Test Results}

The following table presents the results of the cross-sectional dependence test, proposed by Breusch and Pagan (1980).

\section{Table 4 Breuch-Pagan LM Test}

\begin{tabular}{|c|c|c|c|}
\hline Test & Statistic & Probability & d.f \\
\hline B-P LM & $9.10^{\star \star}$ & 0.02 & 3 \\
\hline
\end{tabular}

Note: ** indicates rejection of null hypothesis at $5 \%$ level of significance.

As can be seen from table 4, the Breusch-Pagan test strongly rejects the null hypothesis of no cross-sectional dependence at $5 \%$ level of significance. This means that a shock which has come from one of the countries, affects the others.

\subsubsection{IPS Unit Root Results}

Since cross-sectional dependence has been determined among countries, we proceed applying the CIPS test proposed by Pesaran (2007). We run the test for each variable up to 4 lags with and without trend.

\section{Table 5 CIPS Test}

\begin{tabular}{|c|c|c|c|c|}
\hline \multicolumn{5}{|c|}{ Level } \\
\hline & GDP & FDI & EXP & UN \\
\hline \multirow{2}{*}{$\begin{array}{c}\text { Intercept } \\
\text { Intercept and trend }\end{array}$} & -1.69 & -2.08 & -1.33 & -1.37 \\
\cline { 2 - 5 } & -1.84 & -2.61 & -1.77 & -1.70 \\
\hline \multicolumn{7}{|c|}{ First Differences } \\
\hline & GDP & FDI & EXP & UN \\
\hline
\end{tabular}




\begin{tabular}{|c|c|c|c|c|}
\hline \multirow{2}{*}{$\begin{array}{c}\text { Intercept } \\
\text { Intercept and trend }\end{array}$} & $-3.85 * * *$ & $-6.07 * * *$ & $-4.28 * * *$ & $-3.62 * * *$ \\
\cline { 2 - 5 } & $-4.28 * * *$ & $-6.28 * * *$ & $-4.47 * * *$ & $-3.75 * * *$ \\
\hline
\end{tabular}

Notes: $* * *$ and $* *$ denotes rejection of null hypothesis at at $1 \%$ and $\% 5$ levels of significance. The null hypothesis of non stationarity is rejected in the case that CIPS statistics is smaller than critical value. The critical values in the case of intercept are -2.64 and -2.33 at $1 \%$ and $5 \%$ levels of significance respectively. In the case of intercept and trend are -3.46 and -3.02 at $1 \%$ and $5 \%$ level respectively.

The results of table 5 support that all variables are not stationary in levels but in their first differences. Considering the first generation unit root tests results, the crosssectional dependence results and the results of second generation unit root test we conclude that GDP, FDI, EXP and UN are integrated of order one (i.e. /(1)). So, we use first differences to analyze the causality in VAR model.

\subsection{Panel Data VAR and Granger Causality Tests Results}

We continue by applying Hausman (1978) test in order to help in choosing between FE and RE estimations. The results of Hausman test are reported in table 6.

\section{Table 6 Hausman Test Results}

\begin{tabular}{|c|c|c|c|c|}
\hline & GDP & FDI & EXP & UN \\
\hline$X^{2}(3)$ & $\begin{array}{c}40.833 \\
(0.000)^{\star \star \star}\end{array}$ & $\begin{array}{c}49.677 \\
(0.000)^{\star \star *}\end{array}$ & $\begin{array}{c}147.376 \\
(0.000)^{\star \star *}\end{array}$ & $\begin{array}{c}16.718 \\
(0.000)^{* \star \star}\end{array}$ \\
\hline
\end{tabular}

Notes: The numbers in parentheses denote p-values. $* * *, * *$ denotes rejection of null hypothesis at the $1 \%$ and $5 \%$ level of significance, respectively. It is a chi-square distribution test with 3 d.f.

The Hausman test results show that we should use the fixed effect model (FEM) in order to estimate the equations of DGDP, DFDI, DEXP and DUN.

We continue applying the Wald test of coefficients in equations (16), (17), (18), (19), in order to find the causality directions between the examined variables. Table 7 presents the estimated panel data VAR(2) with the dummy variable for the fifteen countries under investigation in four FEM. The Granger causality directions are based on the Wald test of coefficients. 
Table 7 Panel data Granger causality tests for the group of countries.

\begin{tabular}{|c|c|c|c|c|c|}
\hline \multirow{2}{*}{\multicolumn{2}{|c|}{$\begin{array}{c}\text { Dependent } \\
\text { Variables } \\
\text { Model }\end{array}$}} & DGDP & DFDI & DEXP & DUN \\
\hline & & FEM & FEM & FEM & FEM \\
\hline \multirow{10}{*}{ Coeff. } & $\begin{array}{c}\text { Constant } \\
\left(\mathrm{C}_{1}\right)\end{array}$ & $\begin{array}{c}16074.69 \\
(0.000)\end{array}$ & $\begin{array}{c}1751.11 \\
(0.159)\end{array}$ & $\begin{array}{c}14035.55 \\
(0.000)\end{array}$ & $\begin{array}{c}0.024 \\
(0.680)\end{array}$ \\
\hline & $\begin{array}{l}\text { DGDP(- } \\
\text { 1) }\left(\mathrm{c}_{2}\right)\end{array}$ & $\begin{array}{c}0.394 \\
(0.000)\end{array}$ & $\begin{array}{c}0.030 \\
(0.644)\end{array}$ & $\begin{array}{l}-0.096 \\
(0.093)\end{array}$ & $\begin{array}{c}-8.37 \mathrm{E}-06 \\
(0.007)\end{array}$ \\
\hline & $\begin{array}{l}\text { DGDP(- } \\
\text { 2) }\left(c_{3}\right)\end{array}$ & $\begin{array}{l}-0.338 \\
(0.000)\end{array}$ & $\begin{array}{c}0.041 \\
(0.529)\end{array}$ & $\begin{array}{l}-0.388 \\
(0.000)\end{array}$ & $\begin{array}{c}1.07 \mathrm{E}-05 \\
(0.005)\end{array}$ \\
\hline & $\begin{array}{c}\text { DFDI(-1) } \\
\left(\mathrm{c}_{4}\right)\end{array}$ & $\begin{array}{c}0.238 \\
(0.000)\end{array}$ & $\begin{array}{l}-0.456 \\
(0.000) \\
\end{array}$ & $\begin{array}{c}0.250 \\
(0.000)\end{array}$ & $\begin{array}{c}-5.14 \mathrm{E}-07 \\
(0.811)\end{array}$ \\
\hline & $\begin{array}{l}\text { DFDI(-2) } \\
\text { (c5) }\end{array}$ & $\begin{array}{c}0.015 \\
(0.739) \\
\end{array}$ & $\begin{array}{l}-0.117 \\
(0.014) \\
\end{array}$ & $\begin{array}{l}-0.027 \\
(0.519) \\
\end{array}$ & $\begin{array}{c}5.29 \mathrm{E}-06 \\
(0.020)\end{array}$ \\
\hline & $\begin{array}{l}\text { DEXP(- } \\
\text { 1) (c6) }\end{array}$ & $\begin{array}{l}-0.309 \\
(0.000)\end{array}$ & $\begin{array}{c}0.044 \\
(0.493)\end{array}$ & $\begin{array}{c}0.032 \\
(0.573)\end{array}$ & $\begin{array}{c}5.16 \mathrm{E}-06 \\
(0.099)\end{array}$ \\
\hline & $\begin{array}{l}\text { DEXP(- } \\
\text { 2) (c7) }\end{array}$ & $\begin{array}{c}0.062 \\
(0.290)\end{array}$ & $\begin{array}{c}-0.157 \\
(0.012) \\
\end{array}$ & $\begin{array}{c}0.180 \\
(0.001)\end{array}$ & $\begin{array}{c}-6.65 E-06 \\
(0.026)\end{array}$ \\
\hline & $\begin{array}{c}\mathrm{DUN}(-1) \\
\text { (c8) }\end{array}$ & $\begin{array}{l}-774.3 \\
(0.373)\end{array}$ & $\begin{array}{l}-604.7 \\
(0.513)\end{array}$ & $\begin{array}{r}-1026.2 \\
(0.210)\end{array}$ & $\begin{array}{c}0.613 \\
(0.000)\end{array}$ \\
\hline & $\begin{array}{c}\mathrm{DUN}(-2) \\
(\mathrm{c} 9)\end{array}$ & $\begin{array}{l}-448.3 \\
(0.573)\end{array}$ & $\begin{array}{c}906.3 \\
(0.326)\end{array}$ & $\begin{array}{l}-744.8 \\
(0.363)\end{array}$ & $\begin{array}{l}-0.142 \\
(0.001)\end{array}$ \\
\hline & Dummy & $\begin{array}{c}-15605.65 \\
(0.000)\end{array}$ & $\begin{array}{r}-9825.2 \\
(0.000)\end{array}$ & $\begin{array}{c}-6940.4 \\
(0.001)\end{array}$ & $\begin{array}{c}0.554 \\
(0.000)\end{array}$ \\
\hline $\begin{array}{l}\text { Wald test } \\
\text { of Coeff. } \\
\text { Causality } \\
\text { Direction } \\
\text { (1) }\end{array}$ & $\begin{array}{c}\text { Ho } \\
\text { F-stat. }\end{array}$ & $\begin{array}{c}\mathrm{B} \\
\mathrm{F}(2,576)=18.84 \\
(0.000) \\
\mathrm{FDI} \rightarrow \mathrm{GDP}^{* * *}\end{array}$ & $\begin{array}{c}A \\
F(2,576)=0.511 \\
(0.599)\end{array}$ & $\begin{array}{c}\mathrm{A} \\
\mathrm{F}(2,576)=33.92 \\
(0.000) \\
\mathrm{GDP} \rightarrow \mathrm{EXP}\end{array}$ & $\begin{array}{c}\mathrm{A} \\
\mathrm{F}(2,576)=6.784 \\
(0.001) \\
\mathrm{GDP} \rightarrow \mathrm{UN}^{* * *}\end{array}$ \\
\hline $\begin{array}{l}\text { Wald test } \\
\text { of Coeff. } \\
\text { Causality } \\
\text { Direction } \\
\text { (2) }\end{array}$ & $\begin{array}{c}\text { Ho } \\
\text { F-stat. }\end{array}$ & $\begin{array}{c}\mathrm{C} \\
\mathrm{F}(2,576)=12.70 \\
(0.00) \\
\mathrm{EXP} \rightarrow G D P^{\star \star *}\end{array}$ & $\begin{array}{c}\mathrm{C} \\
\mathrm{F}(2,576)=3.174 \\
(0.042) \\
\mathrm{EXP} \rightarrow \mathrm{FDI}^{\star *}\end{array}$ & $\begin{array}{c}\mathrm{B} \\
\mathrm{F}(2,576)=27.10 \\
(0.000) \\
\mathrm{FDI} \rightarrow \mathrm{EXP}\end{array}$ & $\begin{array}{c}\mathrm{B} \\
\mathrm{F}(2,576)=3.721 \\
(0.024) \\
\mathrm{FDI} \rightarrow \mathrm{UN}^{* *}\end{array}$ \\
\hline $\begin{array}{l}\text { Wald test } \\
\text { of Coeff. } \\
\text { Causality } \\
\text { Direction } \\
\text { (3) }\end{array}$ & $\begin{array}{c}\text { Ho } \\
\text { F-stat. }\end{array}$ & $\begin{array}{c}\mathrm{D} \\
\mathrm{F}(2,576)=1.054 \\
(0.349)\end{array}$ & $\begin{array}{c}\mathrm{D} \\
\mathrm{F}(2,576)=0.501 \\
(0.606)\end{array}$ & $\begin{array}{c}\mathrm{D} \\
\mathrm{F}(2,576)=2.312 \\
(0.099) \\
\mathrm{UN} \rightarrow \mathrm{EXP}^{*}\end{array}$ & $\begin{array}{c}\mathrm{C} \\
\mathrm{F}(2,576)=3.023 \\
(0.049) \\
\mathrm{EXP} \rightarrow \mathrm{UN}^{* *}\end{array}$ \\
\hline
\end{tabular}

Notes: The numbers in parentheses denote p-values. ***, **** denotes rejection of null hypothesis at the $1 \%, 5 \%$ and $10 \%$ level of significance, respectively. $\mathrm{H}_{0}=$ null hypothesis, F-stat=F-statistic. In Wald test of coefficients, the null hypothesis $\mathrm{A}$ is $\mathrm{c}_{2}=\mathrm{c}_{3}=0$, $\mathrm{B}$ is $\mathrm{c}_{4}=\mathrm{c}_{5}=0, \mathrm{C}$ is $\mathrm{c}_{6}=\mathrm{c}_{7}=0, \mathrm{D}$ is $\mathrm{c}_{8}=\mathrm{c}_{9}=0$ respectively. Hausman test is used in the selection of fixed or random effects model.

From the results of table 7 for the fifteen countries viewed as a group, we see that:

The coefficients of the dummy variables are negative, which mean that economic crisis had significant negative impact on these economies.

From the first equation (DGDP) of table 7 we see that there is a unidirectional causality relationship running from foreign direct investments to economic growth and a unidirectional causality running from exports to economic growth. These findings indicate that FDI and exports are important determinants for increasing economic 
development. The results support the export-led growth and the FDI-led growth in these economies, as group.

From the second equation (DFDI) we find that there is only one unidirectional causality relationship between exports and foreign direct investments with direction from exports to FDI. Obviously, it seems that an increase in exports is a vital factor for attracting foreign direct investments. The expansion of exports has a significant impact on FDI. Exports in combination with other factor such as tax breaks, low bureaucracy, proper administration can be the trigger for more FDI.

From the third equation (DEXP) of table 7 we see that there are three unidirectional causalities running from economic growth to exports, foreign direct investments to exports and from unemployment to exports. We can point out according to the results, that the increase in domestic products of these countries and the large amount of foreign direct investments inflows are two beneficial factors that can promote exports. FDI inflows promote exports significantly through capital accumulation. So, an appropriate development strategy, such as providing incentives for economic growth and foreign direct investments can lead to export growth. Also, findings suggest that unemployment has a small impact on exports, barely significant at $10 \%$ level of significance.

Furthermore, from the fourth equation (DUN) of table 7 we find that there are three unidirectional causality relationships running from economic growth to unemployment, foreign direct investments to unemployment and from exports to unemployment. The growth of GDP and the expansion of exports increase output growth and usually increase domestic employment. So, domestic companies will need more labor force to create products. Moreover, the results show that FDI inflows can be a solution in unemployment reduction. FDI enhances private investments, transfer knowledge and technological skills in the workforce and encourages the creation of new jobs. The above results verify that FDI and exports are crucial forces which not only increase GDP but also help in reducing unemployment.

Summarizing the results of table 7 we see that there are three bidirectional causalities between exports and economic growth, exports and FDI, and exports and unemployment and three unidirectional causalities running from FDI to economic growth, from FDI to unemployment, and from economic growth to unemployment. The knowledge about the direction of causality helps policy makers to develop a proper economic policy. So, the policy priority of these countries seems to be the attraction of more and better FDI under the export promotion regime.

\section{Concluding Remarks and Policy Implications}

The enlargement 0 the European Union on May 1 $1^{\text {st }}, 2004$ by ten countries was the biggest on EU's history. Since then, two smaller enlargements followed in 2007 and 2013 respectively. It is a common view that these enlargements have changed the framework for economic activities in Europe. The majority of the new EU members, as 
opposed to the old members, are low income and least developed countries. However, the thirteen new member states have not, so far, diverted away significant amounts from the old members. Lower cost production is one but not the only factor for attracting FDI.

The current economic crisis which started in 2008 has caused serious problems in many European countries and proved that European economies are mutually dependent. The crisis has created many concerns about the cohesion of the Eurozone and subsequent of the European Union. The impact of FDI on economic performance it has been the focus of a considerable number of academic studies on both developing and developed countries. Most of the studies showed that FDI has a positive effect in host countries economies. FDI can be a useful vehicle to promote exports, boost economic development, promote technical innovation and help in reducing unemployment. In recent years many European countries have been interested in attracting FDI in order to promote their economic performance and enhance domestic employment.

In this study we investigate the dynamic interactions among FDI, exports, unemployment, and economic growth in the fifteen old EU members using panel data for the period 1970 to 2015 . The obtained results for these countries, as group, indicated that there are three bidirectional causality relationships between economic growth and exports, exports and FDI, and between exports and unemployment and three unidirectional causalities running from FDI to economic growth, FDI to unemployment and from economic growth to unemployment. The main findings of this study support the export-led growth and the FDI-led growth in these economies and verify that FDI and exports are important determinants from promoting economic growth and reducing unemployment. The results might suggest that the policy priority of these countries seems to be the attraction of more FDI under the export promotion regime.

The main objective of all the governments is the connection of growth and investments. FDI is one of the main determinants for sustainable economic growth. However, the creation of a favorable economic environment for attracting FDI has several components. A stable economic environment and political stability in the host countries is a precondition for any kind of private investments. In addition, policy makers should implement policies that have to do with lower taxes and the reduction of the production cost. Changes in labor cost can be achieved through productivity effects (e.g reducing low-skilled labor). So, policy makers should focus on the development, the education and the training of human capital. Finally, the geographic position of a country and the quantity and the quality of communication systems are factors that can also influence significantly the amount of inward FDI in a host country.

It is a common view that high amounts of inward FDI in combination with a proper export strategy can have a significant positive impact on economic performance. Success in export expansion should be an integral part of an overall industrialization strategy and have to be linked with other policy tools. Success in national export promotion strategy demands the proper coordination between private sector and government. The governments have to cooperate with the national firms, provide them incentives (e.g. tax reliefs, export subsidies, interest rate subsidy) and generally help them overcome 
barriers to exporting. Moreover, governments have to train exporters (including global standards and technology) and give them the necessary market and industry information so to design policies that cover specific needs of buyers and not generally improve the supply side. The role of higher education is a key factor in order to be created high qualified export-oriented business. Finally, for countries with small production base, profits should come from added value and from markets with specific characteristics which are willing to pay more.

\section{References}

Aktar, I., \& Ozturk, L. (2009). Can unemployment be cured by economic growth and foreign direct investment in Turkey? International Research Journal of Finance and Economics, 27, 203-211.

Annual Macro-Economic Database (AMECO). (2014). European Commission, Economic and Financial Affairs. European Commission: AMECO.

Arellano, M. (1993). On the testing of correlated effects with panel data. Journal of Econometrics, 59, (12), 87-97. https://doi.org/10.1016/0304-4076(93)90040-C

Bailey, D., \& Driffield, N. (2007). Industrial policy, FDI and employment: Still missing a strategy. Journal of Industry, Competition and Trade, 7(3), 189-211. https://doi.org/10.1007/s10842-006-7185-8

Baltagi, B.H. (1988). Panel Data Methods. In Handbook of Applied Economic Statistics (A. Ullah \& D.E.A. Giles, Ed.). New York: Marcel Dekker.

Baltagi, B.H. (2005). Econometric Analysis of Panel Data $3^{\text {rd }}$ edition. West Sussex: John Wiley \& Sons.

Borensztein, E., De Gregorio, J., \& Lee, J.W. (1998). How does foreign direct investment affect economic growth? Journal of International Economics, 45, 115-135. https://doi.org/10.1016/S00221996(97)00033-0

Brady, D., \& Wallace, M. (2000). Spatialization, foreign direct investment, and labor outcomes in the American States 1978-1996. Social Forces, 79(1), 67-105. https://doi.org/10.1093/sf/79.1.67

Breusch, T.S., \& Pagan, A.R. (1980). The Lagrange Multiplier Test and its Application to Model Specifications in Econometrics. Review of Economic Studies, 47, 239-253. https://doi.org/10.2307/2297111

Cameron, A.C., \& Trivedi, P.K. (2005). Microeconometrics Methods and Applications. New York: Cambridge University Press. https://doi.org/10.1017/CBO9780511811241

Chang, S.C. (2005). The dynamic interactions among foreign direct investment, economic growth, exports and unemployment: evidence from Taiwan. Economic Change and Restructuring, 38(3), 235-256.

Ciftcioglu, S., Fethi, S., \& Begovic, N. (2007). The impact of net inflows of foreign direct investment on economic growth, unemployment and openness: A panel data analysis of nine central and east European countries. The Journal of Global Business Management, 3(2), 89-94.

De Hoyos R.E., \& Sarafidis, V. (2006). On Testing for Cross-Sectional Dependence in Panel Data Models. The Stata Journal, 6(4), 482-496. 
De Mello, L.R. (1997). Foreign direct investment in developing countries and growth: A selective survey. The Journal of Development Studies, 34(1), pp. 1-34. https://doi.org/10.1080/00220389708422501

Denisia, V. (2010). Foreign direct investment theory: An overview of the main FDI theories. European Journal of Interdisciplinary Studies, 2(2), 104-110.

Dickey, D.A., \& Fuller, W.A. (1979). Distribution of the estimators for autoregressive time series with a unit root. Journal of the American Statistical Association, 74(366), 427-431. https://doi.org/10.2307/2286348

Dickey, D.A., \& Fuller, W.A. (1981). Likelihood ratio statistics for autoregressive time series with a unit root. Econometrica, 49(4), 1057-1072. https://doi.org/10.2307/1912517

Dritsakis, N., \& Stamatiou, P. (2014). Exports, foreign direct investment and economic growth for five European countries: Granger causality tests in panel data. Applied Economics Quarterly, 60(4), 253-272. https://doi.org/10.3790/aeq.60.4.253

Greene, W.H. (2003). Econometric Analysis 5th edition. New Jersey: Prentice Hall.

Hausman, J.A. (1978). Specification tests in econometrics. Econometrica, 46(6), 1251-1271. https://doi.org/10.2307/1913827

Hsiao, C. (2003). Analysis of Panel Data 2nd edition. Cambridge: Cambridge University Press. https://doi.org/10.1017/CBO9780511754203

Huang, X., \& Zhang, M. (2007). The FDl's effects on employment: Based on panel Var. Journal of Central University of Finance \& Economics, 11, 5-20.

Im, K.S., Pesaran, M.H., \& Shin, Y. (2003). Testing for unit roots in heterogeneous panels. Journal of Econometrics, 115(1), 53-74. https://doi.org/10.1016/S0304-4076(03)00092-7

Kunst, R.M. (2009). Econometric methods for panel data - Part II. University of Vienna. Available at: http://homepage.univie.ac.at/robert.kunst/panels2e.pdf

Mehrara, M., Haghnejad, A., \& Dehnavi, J. (2014). Dynamic causal relationships among GDP, exports and foreign direct investment (FDI) in the developing countries. International Letters of Social and Humanistic Sciences, 14(3), 1-19.

Pesaran, M.H. (2004). General Diagnostic Tests for Cross Section Dependence in Panels. Cambridge Working Papers in Economics, No. 435.

Pesaran, M.H. (2007). A Simple Panel Unit Root Test in Presence of Cross Section Dependence. Journal of Applied Econometrics, 22, 265-312. DOI: 10.1002/jae.951.

Stamatiou, P., \& Dritsakis, N. (2014). The impact of foreign direct investment on the unemployment rate and economic growth in Greece: A time series analysis. In proceedings of International WorkConference on Time Series Analysis (ITISE), Granada, June 25-27, 2014, 1, 97-108 (I.R. Ruiz, \& G.R. Garcia Ed.). Granada: Copicentro Granada S.L.

United Nations Conference on Trade and Development (UNCTAD). (2014). Statistics, Data Center. Geneva: UNCTAD. 
World Development Indivcators (WDI). (2014). The World Bank, World Development Indicators. Washington: The World Bank.

Yilmaz, B. (2014). Effects of economic growth, export and foreign direct investment inflows on unemployment in Turkey. Investment Management and Financial Innovations, 11(2). 